\title{
PCB composition in flood material and sediments from the Guadiana River estuary
}

\section{Composición de PCB en el material y los sedimentos de inundación del estuario del Río Guadiana}

\author{
Marta Martins \\ Ana Maria Ferreira* \\ Carlos Vale \\ Instituto de Investigação das Pescas e do Mar \\ Av. Brasilia, 1449-006 Lisboa \\ Portugal \\ * E-mail: amfer@ipimar.pt \\ Recibido en junio de 2003; aceptado en abril de 2004
}

\begin{abstract}
Coarse material and freshly deposited particles transported by the exceptional flood of January 2001 were sampled at eight sites along the Guadiana River and estuarine shorelines. Two months after moderate river flows, we collected 27 surface sediments from the river-estuarine system and one sediment core from the coastal area. The PCB levels in sediments were lower than $1.1 \mathrm{ng} \mathrm{g}^{-1}$, which is in conformity with the absence of industrial activities in the Guadiana drainage basin. Material transported by the flood contained higher PCB concentrations $\left(0.8-1.8 \mathrm{ng} \mathrm{g}^{-1}\right)$ than surface sediments $\left(0.1-1.1 \mathrm{ng}^{-1}\right)$, indicating the importance of these events in the transport of PCB to this low-contaminated estuarine system. These differences were not related to organic carbon content. Furthermore, this material is enriched in less chlorinated compounds as usually occurs far away from point sources. The diffuse transport influences the CB composition of sediment deposits on the adjacent coast, as revealed by variations in the depth profiles of the tri-/hexa-chlorinated ratio, organic carbon content and Si/Al ratio.
\end{abstract}

Key words: PCB, congeners, sediments, flood material, Guadiana River.

\section{Resumen}

Se analizaron el material grueso y las partículas recién depositadas transportadas por la inundación excepcional de enero de 2001 en ocho puntos del Río Guadiana y los márgenes del estuario. Después de dos meses de caudal moderado, se recolectaron 27 muestras de sedimento superficial en el sistema fluvial-estuarino y un core de sedimento en la zona costera. Los niveles de PCB en los sedimentos estuvieron por debajo de $1.1 \mathrm{ng} \mathrm{g}^{-1}$, lo cual concuerda con la ausencia de actividades industriales en la cuenca hidrográfica del Guadiana. Las concentraciones de PCB fueron mayores en el material transportado por la inundación (0.8-1.8 $\left.\mathrm{ng} \mathrm{g}^{-1}\right)$ que en los sedimentos superficiales (0.1-1.1 $\left.\mathrm{ng} \mathrm{g}^{-1}\right)$, lo que demuestra la importancia de estos eventos en el transporte de PCB a este sistema estuarino poco contaminado. Estas diferencias no se relacionaron con el contenido de carbono orgánico. Además, este material se encuentra enriquecido de compuestos menos clorados como es usual en lugares alejados de las fuentes puntuales. El transporte difuso afecta la composición de bifenilos clorados de los sedimentos depositados en la costa adyacente, según muestran las variaciones de la relación triclorados/hexaclorados, el contenido de carbono orgánico y la relación $\mathrm{Si} / \mathrm{Al}$, en los perfiles de profundidad.

Palabras clave: PCB, congéneres, sedimentos, material de inundación, Río Guadiana.

\section{Introduction}

Polychlorinated biphenyls (PCBs) are among the most widespread and persistent contaminants in the coastal environment, being sorbed onto suspended particulate matter and bottom sediments (Dannenberger, 1996; Guruge and Tanabe, 2001; Lee et al., 2001). These compounds may be supplied to the coastal zones through river inputs (Van Zoest and Van Eck, 1990), atmospheric deposition (Sanders et al., 1996), spills (Ferreira and Vale, 2000) and dumping of dredging material (Tang and Myers, 2002). Estuaries in particular tend to accumulate large amounts of polluted riverine particulate matter,

\section{Introducción}

Los bifenilos policlorados (PCB) se encuentran entre los contaminantes más dispersos y persistentes en el ambiente costero ya que se adsorben a la materia particulada suspendida y a los sedimentos en el fondo (Dannenberger, 1996; Guruge y Tanabe, 2001; Lee et al., 2001). Estos compuestos pueden ser incorporados a las zonas costeras mediante el aporte fluvial (Van Zoest y Van Eck, 1990), la depositación atmósferica (Sanders et al., 1996), los derrames (Ferreira y Vale, 2000) y la descarga de material de dragado (Tang y Myers, 2002). Los estuarios, en particular, tienden a acumular grandes cantidades 
contributing to the environmental stress on the estuarine ecosystems (Van Zoest and Van Eck, 1990). As a result of international restrictions on manufacture and use of PCBs, their direct discharges by industry became less common (Connell et al., 1998). Trace quantities of these pollutants are also introduced into the aquatic environment during storm water runoff with diffuse sources progressively replacing the active point sources (Makepeace et al., 1995).

Before reaching the estuarine zone, the Guadiana River crosses approximately $130 \mathrm{~km}$ of a rural area where there are no point sources of PCBs. The fluvial regime is characterized by low flows in summer $\left(79 \mathrm{~m}^{3} \mathrm{~s}^{-1}\right)$ and episodic runoff periods in winter (thousands $\mathrm{m}^{3} \mathrm{~s}^{-1}$ ), carrying eroded soil particles from the drainage basin. This fluvial-estuarine system thus appears to be a suitable environment to assess the importance of diffuse sources associated with river runoff in the transport of PCB to the coastal zone.

\section{Sampling and methods}

Coarse material and freshly deposited particles transported by the Guadiana River after an exceptional episode of river flooding in January 2001 ( $\max .1200 \mathrm{~m}^{3} \mathrm{~s}^{-1}$ ) were collected along $70 \mathrm{~km}$ of the river and estuarine shorelines (fig. 1). At

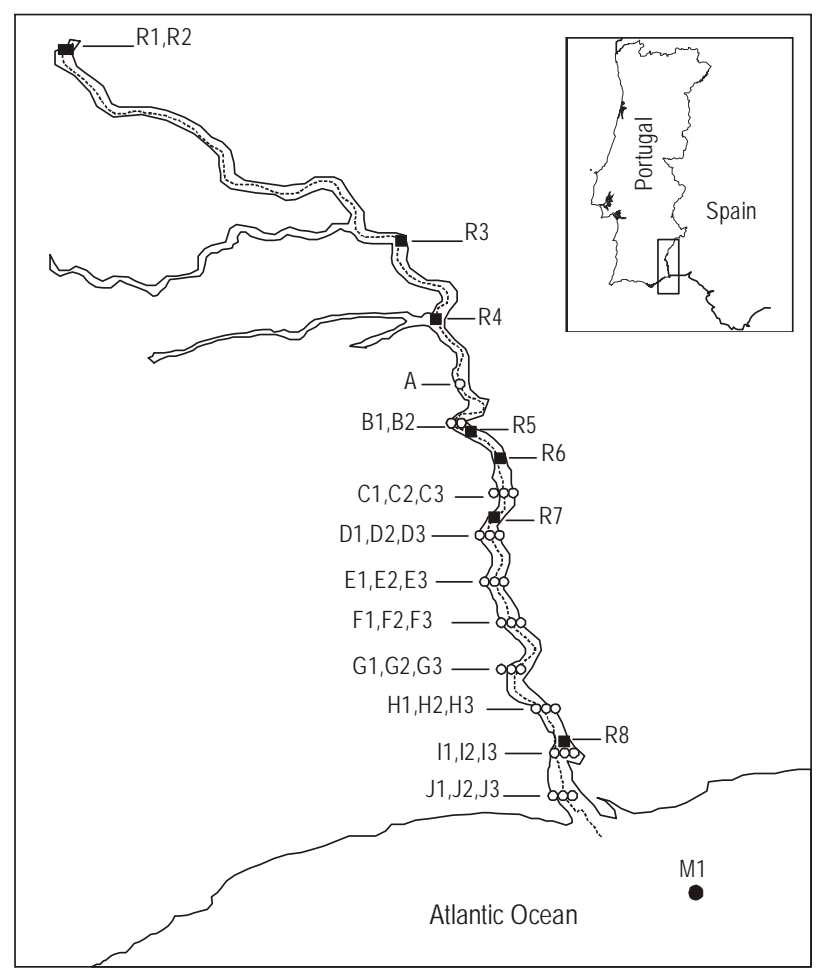

Figure 1. Location of the sampling stations in the Guadiana river-estuarine system: coarse material and freshly deposited particles transported by the river flood $(\boldsymbol{\square})$, surface sediments $(O)$ and sediment core $(\bullet)$.

Figura 1. Localización de las estaciones de muestreo en el sistema fluvialestuarino de Guadiana: material grueso y partículas recién depositadas transportadas por la inundación del río $(\boldsymbol{\square})$, sedimentos superficiales $(O)$ y núcleo de sedimento $(\bullet)$. de material particulado contaminado procedente de los ríos, lo que contribuye al estrés ambiental de los ecosistemas estuarinos (Van Zoest y Van Eck, 1990). A raíz de las restricciones internacionales sobre la producción y el uso de los PCBs, disminuyeron sus descargas industriales directas (Connell et al., 1998). Este contaminate, en pequeñas cantidades, es incorporado en el ambiente acuático mediante las escorrentías pluviales, por intermedio de fuentes difusas que progresivamente, están sustituyendo las fuentes activas puntuales (Makepeace et al., 1995).

Antes de llegar a la zona estuarina, el Río Guadiana cruza aproximadamente $130 \mathrm{~km}$ de un área rural donde no existen fuentes puntuales de PCB. El régimen fluvial se caracteriza por aguas someras en verano $\left(79 \mathrm{~m}^{3} \mathrm{~s}^{-1}\right)$ y periodos de escurrentía en invierno (miles $\mathrm{m}^{3} \mathrm{~s}^{-1}$ ), transportando partículas erosionadas de la cuenca hidrográfica. Por tanto, este sistema fluvialestuarino parece ser un ambiente apropiado para evaluar la importancia de fuentes difusas asociadas a la escorrentía fluvial en el transporte de los PCBs en la zona costera.

\section{Materiales y métodos}

Después de un periodo excepcional de inundación en enero de 2001 (máx. $1200 \mathrm{~m}^{3} \mathrm{~s}^{-1}$ ), se recogió material grueso y partículas recién depositadas que fueron transportadas por el Río Guadiana , a lo largo de $70 \mathrm{~km}$ en los márgenes del río y estuario (fig. 1). Durante el máximo de la inundación, el río transportó material más grueso que fue muestreado en una zona plana del margen derecho (estación R1). A medida que el caudal empezó a diminuir, el río transportó partículas más finas que se depositaron en los márgenes. Estos depósitos parduscos se muestrearon una semana después de la inundación en siete estaciones (R2 a R8) a lo largo del río y en la zona estuarina (fig. 1). En marzo de 2001, cuando el caudal estaba moderado, se recolectaron 27 muestras de sedimento superficial, con una draga, en varias secciones transversales de la misma zona fluvial-estuarina (estaciones A a J). En cada sección transversal se recolectaron de una a tres muestras. Los sedimentos consistieron en una mezcla de arena y partículas finas. Para realizar el análisis químico, en cada estación se escogió la primera capa de $2 \mathrm{~cm}$ de los sedimentos muestreados. Durante el mismo periodo se recolectó un core de sedimento (estación M1) con un multicorer Midicorer Mark II-400, equipado con tubos transparentes, en la zona costera adyacente al estuario del Guadiana (fig. 1). La observación visual de los cores muestra capas intermedias de lodo y arena, con una capa compacta de arena cerca de la superficie. Uno de los cuatro cores recogidos fue seleccionado y dividido a bordo en capas de $2 \mathrm{~cm}$ de espesor hasta los $36 \mathrm{~cm}$ de profundidad. Las muestras fueron congeladas hasta su análisis en el laboratório.

Se analizaron el aluminio, el silicio, el carbono orgánico $\left(\mathrm{C}_{\mathrm{org}}\right)$ y los congéneres de PCB en el material. Se determinó el $\mathrm{C}_{\text {org }}$ en un analizador elemental Carlo Erba, antes y después de calentar las muestras a $450^{\circ} \mathrm{C}$. El aluminio y el silicio fueron determinados mediante espectrofotometría de absorción 
the flood peak, the river transported coarser material that was sampled from a flat area of the right margin (station R1). During the declining flood phase, the river transported finer particles that were deposited on the margins. These brownish deposits were sampled one week after the flood at seven stations (R2 to R8) along the river and estuarine zone (fig. 1). In March 2001, after the river had reached moderate flows, 27 surface sediments were collected with a grab at several crosssections of the same river-estuarine zone (stations A to J). At each cross-section, one to three samples were collected. Sediments consisted of a mixture of sand and fine particles. At each station, the first 2-cm layer of the sampled sediments was chosen for chemical analysis. In the same period, one sediment core (station M1) was sampled with a multicorer Midicorer Mark II-400 equipped with transparent tubes in the coastal area adjacent to the Guadiana estuary (fig. 1). The visual observation of the cores evidences mud-sand interlayers, with a thicker sand layer near the surface. One of the four cores collected was selected and sliced on board in layers of 2-cm thickness until $36-\mathrm{cm}$ depth. All samples were stored frozen until analysis in the laboratory.

Aluminium, silicon, organic carbon $\left(\mathrm{C}_{\text {org }}\right)$ and $\mathrm{PCB}$ congeners were analyzed in all the material; $\mathrm{C}_{\text {org }}$ was analyzed in a Carlo Erba Elemental Analyzer, before and after heating the samples at $450^{\circ} \mathrm{C}$. Aluminium and silicon were determined by atomic absorption spectrophotometry after acid digestion described by Rantala and Loring (1977). For PCB analysis, dry sediment samples were Soxhlet extracted with n-hexane for $16 \mathrm{~h}$. The extracts were cleaned up with Florisil and sulphuric acid following the procedure described in Ferreira and Vale (2001). The elemental sulphur was removed with activated copper. The PCB congeners were analyzed using a HewlettPackard 6890 gas chromatograph with an electron capture detector and a capillary column (DB5, J\&W, $60 \mathrm{~m}$ ). In this study, PCB means the sum of congeners (CB) with IUPAC numbers: tri- $(18,26,31)$, tetra- $(44,49,52)$, penta- $(101,105$, $118)$, hexa- $(128,138,149,151,153)$ and hepta-CB $(170,180$, 183). All concentrations are expressed on a dry weight basis.

\section{Results}

\section{Salinity gradients along the river-estuarine zone}

During the flood period in January 2001, fresh water filled almost the entire estuarine zone, salinity reaching 5 only at the outlet channel of the estuary (cross-section J). During the campaign of March 2001, the river flows were back to moderate values and salinity ranged from 1 to 35 in the estuarine zone between cross-sections D and G.

\section{Organic carbon content}

Coarser material and freshly deposited particles transported by the flood presented a broad range of $C_{\text {org }}(0.4-2.8 \%)$, as well atómica después de digestión ácida, según lo descrito por Rantala y Loring (1977). Para el análisis de los PCBs, éstos fueron extraídos de las muestras de sedimento seco mediante extracción Soxhlet con n-hexano durante 16 h. Los extraxtos se limpiaron con Florisil y ácido sulfúrico de acuerdo con el procedimiento descrito en Ferreira y Vale (2001). Se eliminó el azufre elemental con cobre activado. Los congéneres de PCB fueron analizados utilizando un cromatóMgrafo de gas Hewlett-Packard 6890 con un detector de captura de electrones y una columna capilar (DB5, J\&W, $60 \mathrm{~m}$ ). En este estudio, PCB resulta de la suma de los congéneres de bifeniles clorados (CB) con los siguientes números de IUPAC: triclorados (18, $26,31)$, tetraclorados $(44,49,52)$, pentaclorados $(101,105$, $118)$, hexaclorados $(128,138,149,151,153)$ y heptaclorados $(170,180,183)$. Todas las concentraciones se expresan en base de peso seco.

\section{Resultados}

\section{Gradientes de salinidad en la zona fluvial-estuarina}

Durante el periodo de inundación en enero de 2001, casi toda la zona estuarina se llenó de agua dulce y la salinidad alcanzó 5 únicamente en el canal de salida del estuario (sección transversal J). Durante la campaña de marzo de 2001, el caudal del río retomó valores moderados y la salinidad varió de 1 a 35 en la zona estuarina entre las secciones transversales $\mathrm{D}$ y $\mathrm{G}$.

\section{Contenido de carbono orgánico}

El material grueso y las partículas recién depositadas transportadas por la inundación presentaron un amplio intervalo de $\mathrm{C}_{\text {org }}$ (0.4-2.8\%), así como los sedimentos superficiales recolectados en el sistema fluvial-estuarino (0.01-3.2\%). Se separaron todas las muestras en dos grupos que contenían niveles estadísticamente diferentes $(P<0.05)$ de $\mathrm{C}_{\text {org: }}$ : un grupo de muestras de bajo contenido en $\mathrm{C}_{\text {org }}(0.01-0.57 \%)$ y otro con contenido moderado de $\mathrm{C}_{\text {org }}(0.97-3.20 \%)$. Las distribuciones longitudinales de $\mathrm{C}_{\text {org }}$ en el estuario del Río Guadiana se muestran en la figura 2. Las partículas recién depositadas (representadas por barras negras) se incluyen en el segundo grupo, mientras que el material más grueso recolectado durante la inundación máxima (barra rayada) tiene un nivel bajo de $\mathrm{C}_{\text {org. }}$. Las partículas recién depositadas fueron encontradas en el sistema estuarino.

En la figura 3 se presentan las distribuciones longitudinales de las concentraciones de PCB en los dos grupos de muestras. Los niveles de PCB son claramente más elevados en el material grueso y las partículas recién depositadas transportadas por la inundación (0.8-1.8 $\left.\mathrm{ng} \mathrm{g}^{-1}\right)$ que en los sedimentos superficiales (0.1-1.1 $\left.\mathrm{ng} \mathrm{g}^{-1}\right)$. Los sedimentos pobres en $\mathrm{C}_{\text {org }}$ presentaron bajas concentraciones de PCB, mientras que el material grueso presentó bajo contenido de $\mathrm{C}_{\text {org }}$ pero concentraciones de PCB similares las del material fino. No se obtuvo una correlación entre PCB y $\mathrm{C}_{\text {org }}$, y la representación de 


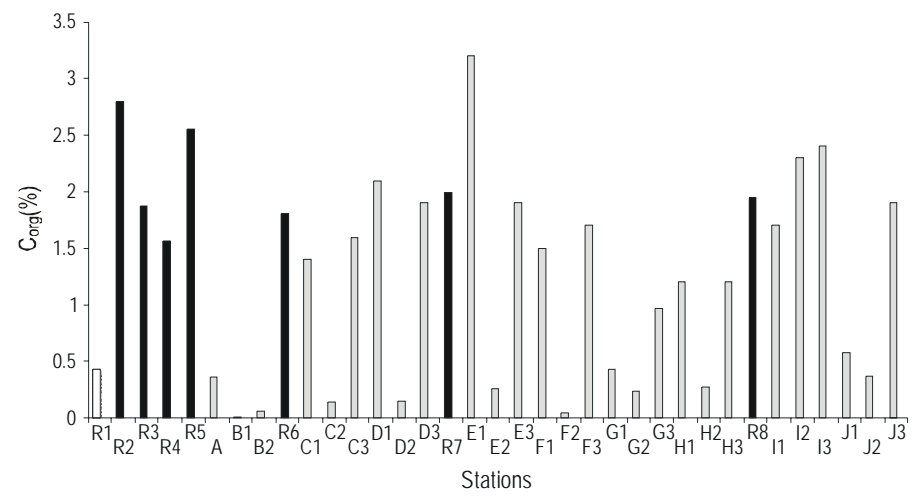

Figure 2. Longitudinal distributions of organic carbon $\left(\mathrm{C}_{\mathrm{org}}, \%\right)$ in coarse material $(\square)$ and freshly deposited particles transported by the river flood ( $(\mathbf{C})$ and in surface sediments ( $\square$ ) collected along the Guadiana river-estuarine system.

Figura 2. Distribuciones longitudinales de carbón orgánico $\left(\mathrm{C}_{\mathrm{org}}, \%\right)$ en el material grueso $(\square)$ y las partículas recién depositadas transportadas por la inundación del río ( $\mathbf{\square}$ ) y en los sedimentos superficales $(\square)$ recolectados a lo largo del sistema fluvial-estuarino de Guadiana.

as surface sediments collected along the river-estuarine system (0.01-3.2\%). All the samples were separated into two groups containing statistically different levels $(P<0.05)$ of $\mathrm{C}_{\text {org }}$ : low $\mathrm{C}_{\text {org }}(0.01-0.57 \%)$ and moderate $C_{\text {org }}$ samples (0.97-3.20\%). The longitudinal distributions of $\mathrm{C}_{\text {org }}$ along the Guadiana River estuary are shown in figure 2. The freshly deposited particles (represented by black bars) are included in the second group, while the coarser material collected at the flood peak (dashed bar) has low $\mathrm{C}_{\text {org }}$. Those freshly deposited particles were found along the estuarine system.

\section{PCB concentrations}

The longitudinal distributions of PCB concentrations in the two sets of samples are presented in figure 3. Clearly, the coarse material and freshly deposited particles transported by the flood contained higher PCB levels (0.8-1.8 $\left.\mathrm{ng} \mathrm{g}^{-1}\right)$ than the surface sediments (0.1-1.1 $\left.\mathrm{ng} \mathrm{g}^{-1}\right)$. Whereas sediments impoverished in $\mathrm{C}_{\text {org }}$ contained low PCB concentrations, the coarse material presented low $\mathrm{C}_{\text {org }}$ but PCB concentrations similar to the fine material. No correlation between PCB and $\mathrm{C}_{\text {org }}$ was obtained and the representation of the $\mathrm{PCB} / \mathrm{C}_{\text {org }}$ ratio presented a similar longitudinal distribution.

\section{PCB composition}

The mean proportions of tri-, tetra-, penta-, hexa- and hepta-chlorinated congeners (percentage of total) in surface sediments and in coarse and freshly deposited particles are compared in figure 4. On average, tri-CB accounted for around $60 \%$ of PCB in these materials, while in surface sediments it was less than $35 \%$. The proportion of hexa- and hepta-CB was slightly higher in the surface sediments.

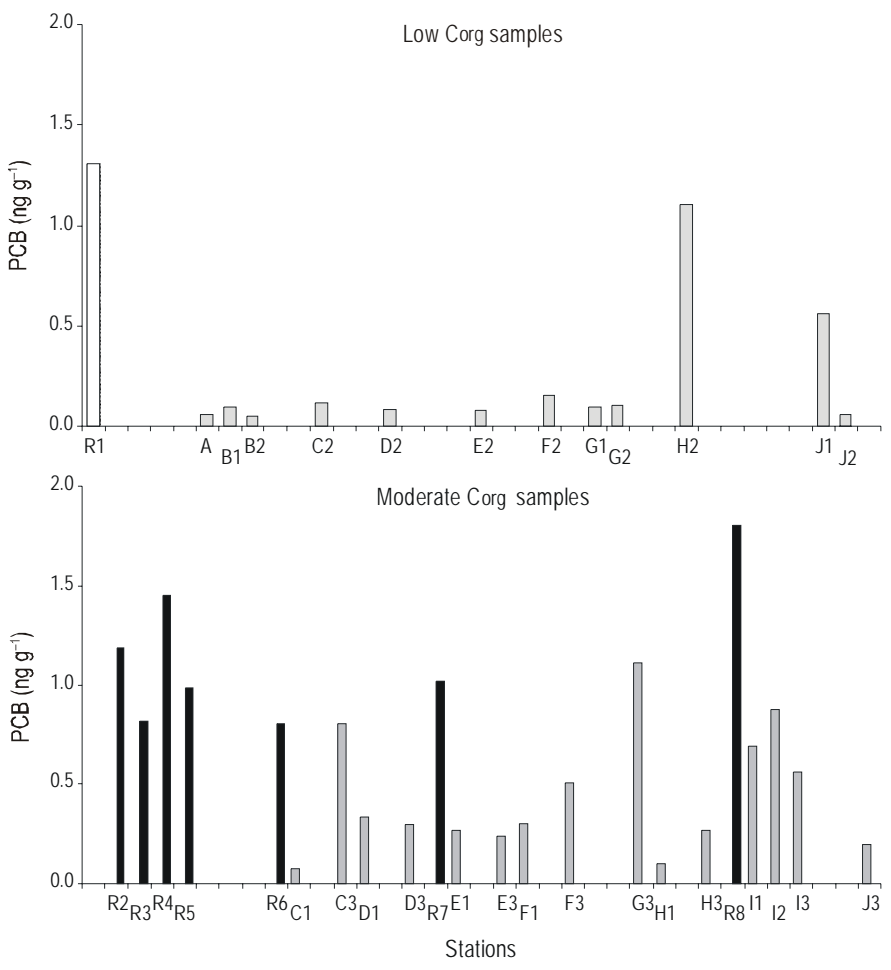

Figure 3. Longitudinal distributions of PCB $\left(\mathrm{ng} \mathrm{g}^{-1}\right)$ in coarse material ( $\square$ ) and freshly deposited particles transported by the river flood ( $\mathbf{(})$ and in surface sediments ( $\square$ ) from the Guadiana river-estuarine system with low and moderate organic carbon $\left(\mathrm{C}_{\text {org }}\right)$ content.

Figura 3. Distribuciones longitudinales de PCB ( $\mathrm{ng} \mathrm{g}^{-1}$ ) en el material grueso ( $\square$ ) y las partículas recién depositadas transportadas por la inundación del río ( $\mathbf{1}$ ) y en los sedimentos superficiales ( $\square$ ) del sistema fluvial-estuarino de Guadiana con contenido de carbón orgánico $\left(\mathrm{C}_{\text {org }}\right)$ bajo y moderado.

la relación $\mathrm{PCB} / \mathrm{C}_{\text {org }}$ presentó una distribución longitudinal similar.

\section{Composición de PCB}

En la figura 4 se comparan las proporciones medias de los congéneres triclorados, tetraclorados, pentaclorados, hexaclorados y heptaclorados (porcentaje total) en los sedimentos superficiales y en el material grueso y las partículas recién depositadas. En media, los triclorados representan cerca del $60 \%$ de los PCB en el material grueso y las partículas recién depositadas, y menos del 35\% en los sedimentos superficiales. La proporción de hexaclorados y heptaclorados fue ligeramente mayor en los sedimentos superficiales.

\section{Relación entre los congéneres triclorados y hexaclorados}

Para ilustrar mejor las diferencias en la composición de PCB entre los materiales transportados por la inundación y los sedimentos superficiales, se calculó la relación entre los niveles de los congéneres triclorados (CB18 + CB26 + CB31) y los hexaclorados (CB128 + CB138 + CB149 + CB151 + 


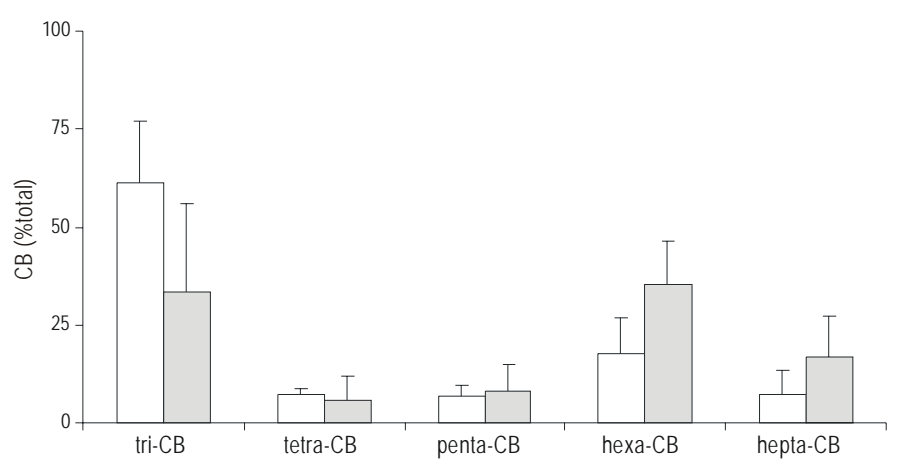

Figure 4. Mean proportions and standard deviation of tri- $\mathrm{CB}$, tetra- $\mathrm{CB}$, penta- $\mathrm{CB}$, hexa-CB and hepta-CB (\% of total) in coarse material and freshly deposited particles $(\square)$ and in surface sediments $(\square)$.

Figura 4. Proporciones medias y desviación estándar de los congéneres triclorados, tetraclorados, pentaclorados, hexaclorados and heptaclorados (\% del total) en el material grueso y las partículas recién depositadas ( $\square$ ) y en los sedimentos superficiales $(\square)$.

\section{Ratio between tri- and hexa-chlorinated congeners}

To better illustrate the differences in PCB composition between materials transported by the flood and surface sediments, the ratio between the levels of tri-CB (CB18 + CB26 + CB31) and hexa-CB (CB128 + CB138 + CB149 + CB151 + CB153) was calculated. The results obtained for samples with low and moderate $\mathrm{C}_{\text {org }}$ contents are presented in two plots (fig. 5). In general, higher ratios were obtained for coarse material and freshly deposited particles transported by the river flood (max. 9.4). Most of the surface sediments containing lower $\mathrm{C}_{\text {org }}$ showed tri-CB/hexa-CB ratios greater than one (max. 3.6), and sediments with moderate levels of $\mathrm{C}_{\text {org }}$ ratios less than one. A few exceptions were registered. Although the longitudinal trend was not well defined, all samples from the lower estuary (sections I and J) presented ratios less than one.

\section{PCB, Si/Al ratio and organic carbon in coastal sediments}

Depth variations of the $\mathrm{Si} / \mathrm{Al}$ ratio, $\mathrm{C}_{\text {org }}$ content, $\mathrm{PCB}$ concentrations and tri- $\mathrm{CB} /$ hexa-CB ratio in the sediment core M1 from the coastal area adjacent to the estuary are presented in figure 6 . The core is characterized by pronounced depth variations of the $\mathrm{Si} / \mathrm{Al}$ ratio and $\mathrm{C}_{\text {org }}$, reflecting interlayers of coarse and fine particles as well as material with a broad range of $\mathrm{C}_{\text {org }}$. The low $\mathrm{C}_{\text {org }}$ in the sub-surface layer $(0.20 \%)$ coincides with the increase of the $\mathrm{Si} / \mathrm{Al}$ ratio (4.1). This layer (5-7 cm depth) showed higher values of PCB ( $\left.0.75 \mathrm{ng} \mathrm{g}^{-1}\right)$ and of the tri-CB/ hexa-CB ratio (4.0) than other sediment layers containing lower values of both $\mathrm{C}_{\text {org }}$ and the $\mathrm{Si} / \mathrm{Al}$ ratio. The second peak of the $\mathrm{Si} / \mathrm{Al}$ ratio recorded between 10 and $14 \mathrm{~cm}$ depth was also accomplished by increases of PCB and of the CB ratio, although the variation of $\mathrm{C}_{\text {org }}$ content was minor. At deeper layers (15-20 cm depth), the sediment presented higher $\mathrm{C}_{\text {org }}$ without substantial alterations in the Si/Al ratio and PCB.
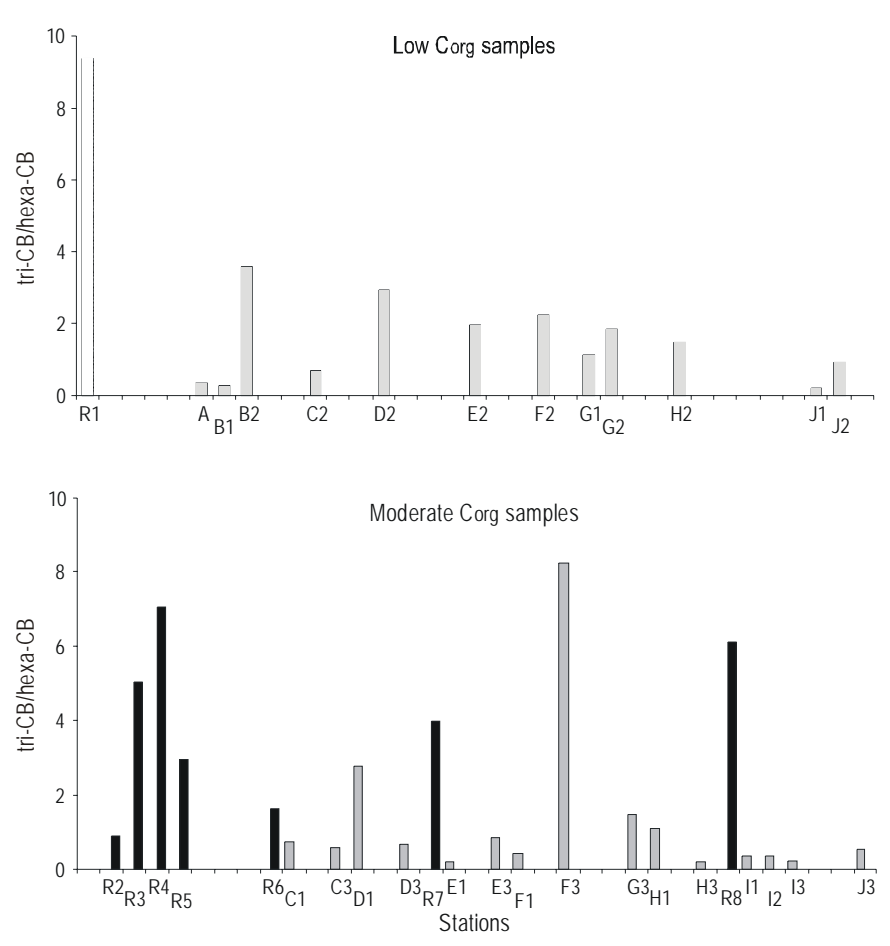

Figure 5. Longitudinal distributions of the tri-CB/hexa-CB ratio in coarse material $(\square)$ and freshly deposited particles transported by the river flood ( $(\mathbf{D})$ and in surface sediments $(\square)$ from the Guadiana river-estuarine system with low and moderate organic carbon $\left(\mathrm{C}_{\text {org }}\right)$ content.

Figura 5. Distribuciones longitudinales de la razón triclorados/hexaclorados en el material grueso $(\square)$ y las partículas recién depositadas transportadas por la inundación del río $(\square$ y en los sedimentos superficiales $(\square)$ del sistema fluvial-estuarino de Guadiana con contenido de carbón orgánico $\left(\mathrm{C}_{\text {org }}\right)$ bajo y moderado.

CB153). Los resultados obtenidos para muestras con contenidos de $\mathrm{C}_{\text {org }}$ bajos y moderados se presentan en dos gráficos (fig. 5). En general, se obtuvieron razones mayores para el material grueso y las partículas recién depositadas transportadas por la inundación (máx. 9.4). La mayoría de los sedimentos superficiales con menor contenido de $\mathrm{C}_{\text {org }}$ presentaron relaciones triclorados/hexaclorados mayores que uno (máx. 3.6), y los sedimentos con contenidos moderados de relaciones de $\mathrm{C}_{\text {org }}$ menores que uno. Se registraron algunas excepciones. Aunque no se obtuvo una tendencia longitudinal bien definida, todas las muestras del estuario bajo (secciones I y J) presentaron relaciones menores que uno.

\section{PCB, relaciones Si/Al y carbono orgánico en sedimentos costeros}

En la figura 6 se presentan las variaciones con la profundidad de la relación $\mathrm{Si} / \mathrm{Al}$, el contenido de $\mathrm{C}_{\text {org }}$, las concentraciones de PCB y la razón triclorados/hexaclorados en el core de sedimento M1 cogido en la zona costera adyacente al estuario. El core se caracteriza por variaciones pronunciadas de la relación $\mathrm{Si} / \mathrm{Al}$ y el $\mathrm{C}_{\text {org }}$ con la profundidad, reflejando capas intermedias de partículas gruesas y finas, así como material 


\section{Discussion}

The low PCB concentrations in sediments from the Guadiana estuary $\left(<2 \mathrm{ng} \mathrm{g}^{-1}\right)$ indicate that this fluvial-estuarine system has a low degree of contamination in comparison to other estuarine systems (Frignani et al., 2001; Jeong et al., 2001). The occurrence of a slight increase of PCB in sediments from the estuarine mouth (G3, H2, I1, I2, I3, J1, fig. 3) suggests, however, the existence of slight point sources in the urbanized areas of the margins. In addition to this increment, the tri-CB/hexa-CB ratio decreased in sediments from this part of the estuary. The predominance of hexa-CB in this area corroborates the hypothesis of local sources, since proportions of higher chlorinated congeners are usually higher near point sources because of lower chlorinated congeners being more volatile, degradable and lost more readily (Lee et al., 2001).

Particles transported by the flood and deposited on the shoreline exhibited higher concentrations of PCB than sediments; however, the proportions of higher chlorinated compounds are lower in comparison to surface sediments. The alterations of $\mathrm{CB}$ composition in conjunction with the absence of industries in the drainage river basin, suggest that the increase of PCB in material transported by river flood resulted from diffuse transport of these compounds rather than from the influence of active point sources. Several works have shown the importance of diffuse sources on the transport and distribution of PCB in coastal environments, associated with storm water runoff (Ferreira and Vale, 1995; Makepeace et al., 1995). The predominance of less chlorinated compounds observed in the coarse and fine soil particles transported by the storm water runoff also reflects the influence of diffuse sources due to the higher mobility of these congeners both in the atmosphere and aquatic milieu (Iwata et al., 1995; Dannenberger, 1996; Lee et al., 2001). The absence of active point sources in the Guadiana drainage basin suggests that lower CB proportions in soil particles are derived from atmospheric transport. The assumption of PCB mixture enriched in less chlorinated congeners from a potential source in remote areas is less realistic, as shown by the enrichment of higher chlorinated congeners in sediments at the mouth of the Guadiana estuary and after an accidental spill in the Tagus estuary (Ferreira and Vale, 2000).

The recognition of alterations occurred in the PCB composition input with floods is of great importance since it is expected that in the future, as point sources decrease or cease, the PCB levels in aquatic systems will be mainly influenced by diffuse transport (Connell et al., 1998). Pulse mechanism, associated with peak river floods, supplies the estuary with material containing predominantly lower CB. These compounds tend to be distributed along the estuary and in certain cases may reach the adjacent coastal zone, as registered by the depth profile of the proportion of tri-CB with respect to hexa$\mathrm{CB}$ in the Guadiana system.

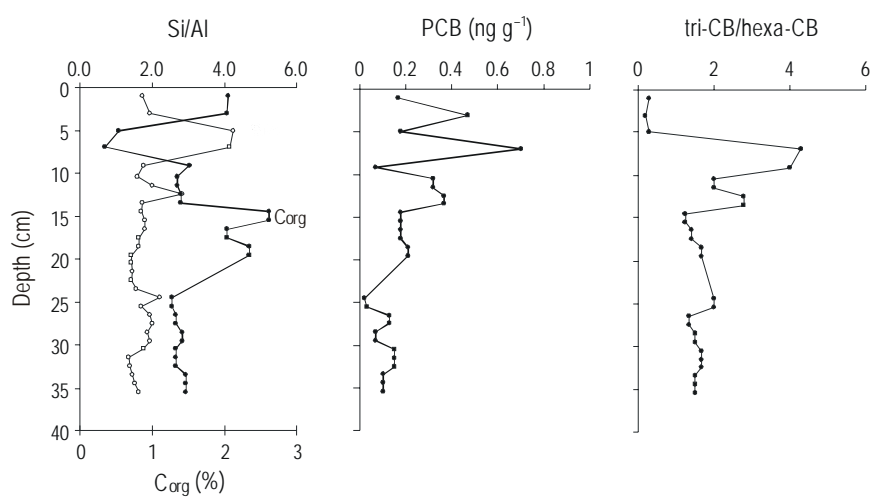

Figure 6. Depth variations of Si/Al ratio, organic carbon $\left(\mathrm{C}_{\text {org }}\right)$ content $(\%)$, $\mathrm{PCB}$ concentrations $\left(\mathrm{ng} \mathrm{g}^{-1}\right)$ and tri-CB/hexa-CB ratio in the sediment core M1 from the adjacent coastal area.

Figura 6. Variaciones con la profunidad de la razón Si/Al, el contenido de carbón orgánico $\left(\mathrm{C}_{\mathrm{org}}, \%\right)$, las concentraciones de PCB $\left(\mathrm{ng} \mathrm{g}^{-1}\right)$ y la razón triclorados/hexaclorados en el núcleo de sedimento M1 de la zona costera adyacente.

con un amplio intervalo de $\mathrm{C}_{\text {org }}$. El bajo contenido de $\mathrm{C}_{\text {org }}$ en el nivel subsuperficial (0.20\%) coincide con el incremento de la relación $\mathrm{Si} / \mathrm{Al}$ (4.1). Esta capa (5-7 cm de profundidad) mostró valores más elevados de PCB (0.75 ng g $\left.{ }^{-1}\right)$ y de la relación triclorados/hexaclorados (4.0) que otras capas de sedimento con valores más bajos tanto de $\mathrm{C}_{\text {org }}$ como de la relación $\mathrm{Si} / \mathrm{Al}$. El segundo pico de la relación $\mathrm{Si} / \mathrm{Al}$ registrado entre 10 y 14 cm de profundidad también coincidió con incrementos en PCB y en la relación $\mathrm{CB}$, aunque la variación del contenido de $\mathrm{C}_{\text {org }}$ fue menor. En los niveles más profundos (15-20 cm de profundidad) el sedimento presentó mayor contenido de $\mathrm{C}_{\text {org }}$ sin alteraciones substanciales en la relación Si/Al y PCB.

\section{Discusión}

Las bajas concentraciones de PCB en los sedimentos del estuario del Rio Guadiana $\left(<2 \mathrm{ng} \mathrm{g}^{-1}\right)$ indican que este sistema fluvial-estuarino tiene un grado de contaminación bajo en comparación con otros sistemas similares (Frignani et al., 2001; Jeong et al., 2001). Por otro lado, el leve aumento de PCB en los sedimentos de la boca del estuario (G3, H2, I1, I2, I3, J1; fig. 3) sugiere la existencia de ligeras fuentes puntuales en las zonas urbanizadas de los márgenes. Además de este aumento, la relación triclorados/hexaclorados decreció en los sedimentos de esta parte del estuario. La predominancia de los congéneres hexaclorados en esta zona corrobora la hipótesis de fuentes locales, ya que las proporciones de los congéneres más clorados tienden a ser mayores cerca de las fuentes puntuales teniendo en cuenta que los congéneres menos clorados son más volátiles, degradables y perdidos con mayor facilidad (Lee et al., 2001).

Las concentraciones de PCB en las partículas transportadas por la inundación y depositadas en los márgenes fueron mayores que en los sedimentos; sin embargo, las proporciones 


\section{References}

Connell, D.W., Wu, R.S.S., Richardson, B.J., Leung, K., Lam, P.S.K. and Connell, P.A. (1998). Occurrence of persistent organic contaminants and related substances in Hong Kong marine areas: An overview. Mar. Pollut. Bull., 36: 376-384.

Dannenberger, D. (1996). Chlorinated microcontaminants in surface sediments of the Baltic Sea: Investigations in the Belt Sea, the Arkona Sea and the Pomeranian Bight. Mar. Pollut. Bull., 32: 772-781.

Ferreira, A.M. and Vale, C. (1995). The importance of runoff to DDT and PCB inputs to the Sado estuary and Ria Formosa. Neth. J. Aquat. Ecol., 29: 211-216.

Ferreira, A.M. and Vale, C. (2000). Aumento dos níveis de PCB nas partículas em suspensão, peixes e moluscos do estuário do Tejo e zona costeira adjacente após um derrame acidental. In: A. Duarte, C. Vale and R. Prego (eds), Estudos de Biogeoquímica na Zona Costeira Ibérica, Universidade de Aveiro, Portugal, pp. 55-60.

Ferreira, A.M. and Vale, C. (2001). Seasonal and inter-annual variations of PCB and DDT contents in the oyster Crassostrea angulata from the Sado estuary (Portugal). Cienc. Mar., 27: 255268.

Frignani, M., Bellucci, L.G., Carraro, C. and Raccanelli, S. (2001). Polychlorinated biphenyls in sediments of the Venice Lagoon. Chemosphere, 43: 567-575.

Guruge, K.S. and Tanabe, S. (2001). Contamination by persistent organochlorines and butyltin compounds in the west coast of Sri Lanka. Mar. Pollut. Bull., 42: 179-186.

Iwata, H., Tanabe, S., Ueda, K. and Tatsukawa, R. (1995). Persistent organochlorine residues in air, water, sediments, and soils from the Lake Baikal region, Russia. Environ. Sci. Technol., 29: 792801.

Jeong, G.H., Kim, H.J., Joo, Y.J., Kim, Y.B. and So, H.Y. (2001). Distribution characteristics of PCBs in the sediments of the lower Nakdong River, Korea. Chemosphere, 44: 1403-1411.

Lee, K.T., Tanabe, S. and Koh, C.H. (2001). Contamination of polychlorinated biphenyls (PCBs) in sediments from Kyeonggi Bay and nearby areas, Korea. Mar. Pollut. Bull., 42: 273-279.

Makepeace, D.K., Smith, D.W. and Stanley, S.J. (1995). Urban stormwater quality: Summary of contaminant data. Rev. Environ. Sci. Technol., 28: 1278-1284.

Rantala, R. and Loring, D. (1977). A rapid determination of 10 elements in marine suspended matter by atomic absorption spectrophotometry. Atomic Absorption Newslett., 16: 51-52.

Sanders, G., Hamilton-Taylor, J. and Jones, K.C. (1996). PCB and PAH dynamics in a small rural lake. Environ. Sci. Technol., 30: 2958-2966.

Tang, N.H. and Myers, T.E. (2002). PCB removal from contaminated dredge material. Chemosphere, 46: 477-484.

Van Zoest, R. and Van Eck, G.T.M. (1990). Behaviour of particulate polychlorinated biphenyls and polycyclic aromatic hydrocarbons in the Sheldt estuary. Neth. J. Sea Res., 26: 89-96. de los compuestos de mayor número de áyomos de cloro fueron menores que en los sedimentos superficiales. Las alteraciones de la composición de CB junto con la ausencia de industrias en la cuenca hidrográfica sugieren que el incremento de PCB en el material transportado por la inundación es principalmente debido al transporte difuso de estos compuestos y en manor grado a la influencia de fuentes puntuales activas. Varios trabajos han mostrado la importancia de fuentes difusas en el transporte y la distribución de PCB en ambientes costeros asociados a la escorrentía (Ferreira y Vale, 1995; Makepeace et al., 1995). La predominancia de compuestos menos clorados en las partículas gruesas y finas transportadas por la escorrentía pluvial también refleja la influencia de fuentes difusas debido a la mayor movilidad de estos congéneres tanto en la atmósfera como en el ambiente acuático (Iwata et al., 1995; Dannenberger, 1996; Lee et al., 2001). La ausencia de fuentes puntuales activas en la cuenca hidrográfica del Guadiana sugiere que las proporciones de congéneres menos clorados están asociadas al transporte atmosférico. Admitir que las fuentes puntuales en áreas remotas contienen mezcla de PCB enriquecida en congéneres menos clorados sería poco realista, pues se demostró qne en los sedimentos la boca del estuario del Guadiana y después de un derrame accidental en el estuario del Tajo (Ferreira y Vale, 2000) es donde se verifica el enriquecimiento de congéneres más clorados.

El reconocimiento de las alteraciones en la composición de PCB con inundaciones es de gran importancia ya que se espera que en el futuro, según decrezcan o desaparezcan las fuentes puntuales, los niveles de PCB en los sistemas acuáticos serán influenciados principalmente por el transporte difuso (Connell et al., 1998). El mecanismo de pulso, asociado con picos máximos de caudales de ríos debidos a las inundaciones proporciona al estuario material que contiene niveles de congéneres menos clorados. Estos compuestos tienden a ser distribuidos a lo largo del estuario y, en algunos casos, pueden llegar a la zona costera adyacente, según lo demuestra el perfil de profundidad de la proporción de congéneres triclorados en relación con los hexaclorados en el sistema del Guadiana.

Traducido al español por Christine Harris. 